\title{
Tolerance of Mycelium of Different Genotypes of Phytophthora infestans to Freezing Temperatures for Extended Periods
}

\author{
William W. Kirk
}

Department of Plant Pathology, Michigan State University, East Lansing 48824.

Accepted for publication 16 May 2003.

\section{ABSTRACT}

Kirk, W. W. 2003. Tolerance of mycelium of different genotypes of Phytophthora infestans to freezing temperatures for extended periods. Phytopathology 93:1400-1406.

Mycelium of Phytophthora infestans, the causal agent of potato late blight, can initiate crop infections over successive years by overwintering in infected potato tubers that survive as seed in fields or within cull piles. This study used four different genotypes of $P$. infestans to evaluate the influence of freezing temperatures on survival of mycelium in vitro. Sporangium-free mycelium of $P$. infestans US1, US8, US11, and US14 growing on rye agar plates was exposed to temperatures ranging from -20 and $0^{\circ} \mathrm{C}$ (experiment $\mathrm{A}$ ) for different periods up to $24 \mathrm{~h}$ and from -5 and $0^{\circ} \mathrm{C}$ (experiment B) for periods up to 5 days. Cultures were incubated at $12^{\circ} \mathrm{C}$ after exposure, and survival of the cultures was estimated after 28 days by a digital image analysis technique that measured the average reflectance intensity (ARI) of images of the mycelium of temperature-treated cultures. The ARI values of treated cultures were compared with the growth of mycelium in negative controls (mycelium not present) and positive controls (mycelium exposed to $12^{\circ} \mathrm{C}$ for an equivalent period), and determination of recovery was based on statistical differences from the controls. There were significant differences in ARI values among genotypes, temperature treatment, and exposure periods in all experiments. An index of recovery was calculated for each genotype at all treatment temperatures and exposure periods for both experiments. In experiment $\mathrm{A}$, exposure of mycelium of $P$. infestans (all genotypes) to -20 and $-10^{\circ} \mathrm{C}$ proved lethal for exposure periods of more than $1 \mathrm{~h}$. All genotypes showed some degree of recovery up to 24-h exposure at -5 and $-3^{\circ} \mathrm{C}$. In both experiments, exposure of mycelium of $P$. infestans to $0^{\circ} \mathrm{C}$ was not lethal to any genotype tested for any exposure period. In experiment $\mathrm{B}$, all of the genotypes survived exposure up to 3 days at $-3^{\circ} \mathrm{C}$ to some degree, but at $-5^{\circ} \mathrm{C}$, exposure of 1 day was lethal to all genotypes. Tolerance of freezing temperatures by mycelium of $P$. infestans may be an ecologically important survival mechanism and the increased tolerance of US8 and US14 may explain their predominance in cooler climates such as north-central United States.

Additional keywords: Peltier effect, Solanum tuberosum.
Late blight of potato, caused by Phytophthora infestans (Mont.) de Bary is a devastating disease that affects all potato growing regions in the world and adversely affects potato production in the northern United States (11). P. infestans overwinters in potato tubers that are intended for replanting as seed $(5,13,19,33)$, but the pathogen may also be harbored in waste or cull potato tubers $(3,33)$ or within volunteer potatoes infected with $P$. infestans returned to the soil during harvest the previous season, although it is generally agreed this latter source of inoculum is of minor importance $(11,33)$. The relative ability of these various sources of inoculum to survive the climate of the north-central regions of the United States and allow the pathogen to overwinter has led to debate (27). Since the early 1990 s, the population of $P$. infestans throughout much of the world was clonal, mefenoxam/metalaxyl-sensitive, and US1/A1 (genotype/mating type [12]). Potato late blight control strategies changed following the migration of mefenoxam/ metalaxyl-resistant populations of $P$. infestans from Mexico to North America $(11,16)$. The predominant genotype in North America is now US8/A2 (genotype/mating type [11,12]). Cultural control methods and crop protection strategies now rely primarily on crop sanitation and protectant foliar fungicide applications $(13,14,17,28,29)$. The continued predominance of the US8 genotype in North America and its genetically close neighbor, the US14 genotype (12), may be due to tolerance of a wider range of environmental conditions than those that could be borne by the now rare US1 genotype.

Corresponding author: W. W. Kirk; E-mail address: kirkw@msu.edu

Publication no. P-2003-0826-01R

(C) 2003 The American Phytopathological Society
The survival of viable host tissue from infection through dormancy to reemergence the following spring is vital for survival of P. infestans $(21,31,33)$. In North America, the probability that infected potato stems or foliage will emerge from an infected tuber is difficult to estimate because several factors can influence the fate of the infected tuber $(24,25,27)$, temperature being one of the most important $(20,26)$.

Many investigators have used in vitro and soil assays to study the optimal and lethal upper temperatures for growth of Phytophthora spp. $(2,4,18,32)$. The survival of $P$. nicotianae chlamydospores in soil was reduced considerably when temperatures were raised above $45^{\circ} \mathrm{C}$ (4). No studies that systematically examine the ability of $P$. infestans mycelium to survive at temperatures below $0^{\circ} \mathrm{C}$ exist, although De Bruyn (7) showed that a mycelial colony was capable of withstanding temperatures as low as $-25^{\circ} \mathrm{C}$ for up to 5 days in manure-based substrate and survival at such low temperatures was enhanced in dried substrates (7). P. infestans can survive at $3^{\circ} \mathrm{C}$ within infected tubers as stored seed (22). However, the fate of mycelium of $P$. infestans within potato tubers exposed to temperatures below $0^{\circ} \mathrm{C}$ has not been monitored. The objectives of this study were to investigate the ability of different genotypes of $P$. infestans obtained from the north-central/Great Lakes region of the United States and Pacific coastal northwest United States to survive in vitro at temperatures below $0^{\circ} \mathrm{C}$ and to determine the duration of exposure at a range of temperatures below $0^{\circ} \mathrm{C}$ that was lethal to mycelium.

\section{MATERIALS AND METHODS}

Isolate descriptions. Cultures of four genotypes of $P$. infestans, US1 (MI95-6), US8 (MI95-7), and US11 (MI96-1), were origi- 
nally isolated from foliage of potato plants with symptoms of late blight grown in north-central/Great Lakes region of the United States and US14 (WA671) from Washington State, respectively, and maintained in the Kirk collection at Michigan State University (MSU). The identity of the genotypes was determined by isozyme analysis (12), mefenoxam sensitivity (6), and mating type (6). The original sources of the isolates were from Michigan; US1, mefenoxam-sensitive, A1 mating type (MI95-6); US8, mefenoxaminsensitive, A2 mating type, (MI95-7); US11, mefenoxam-insensitive, A1 mating type (MI96-1); and US14, mefenoxam-insensitive, A2 mating type (WA671). The isolates were maintained on sterile rye seed stock cultures. Isolates were repropagated from the long-term storage stock culture for each experiment on rye agar.

Substrate optimization and digital image analysis. The optimal volume of sterol-free clarified rye agar (SFCRA) that could be added to 60 -mm-diameter petri dishes in order to measure the reflectance characteristics by digital image analysis (described below) was determined. Sterol added to growth media enhances sporulation (6). SFCRA was prepared by washing $100 \mathrm{~g}$ of organically produced rye seed, boiling for $1 \mathrm{~h}$ in distilled $(\mathrm{d}) \mathrm{H}_{2} \mathrm{O}$, straining the suspension through cheesecloth, and adding $15 \mathrm{~g}$ of agar, $7.5 \mathrm{~g}$ of sucrose, and $\mathrm{dH}_{2} \mathrm{O}$ to bring the solution to 1-liter final volume. Volumes of 5, 10, 15, and $20 \mathrm{ml}$ of SFCRA were poured into petri dishes.

The reflectance intensity of the petri dishes with different volumes of SFCRA was then determined by digital image analysis. The scanned images were the SFCRA petri dishes without cover lids. The petri dishes were placed open-surface down on a glass plate, $40 \times 30 \times 0.2 \mathrm{~cm}$ thick, and digital images were generated and analyzed as described previously (22). The average reflective intensity (ARI) of all the pixels within the image gave a measurement of the plate without any growth of the sample. The calibrations resulted in optimal agar volumes of $10 \mathrm{ml}$ of substrate per 60 -mm-diameter petri dishes with mean $\mathrm{ARI}=90$.

Relation of digital image of samples to weight of mycelium. Mycelium of $P$. infestans is white and the ARI of a digital image of a mature culture measures about 150 to 170 light intensity units (LIU; Fig. 1). To determine the relation between ARI of cultures of $P$. infestans growing on SFCRA and fresh weight of the cultures, a further calibration was attempted. Sterile cellophane disks (40-mm-diameter) were placed over SFCRA and 5-mm-diameter plugs of mycelium were transferred to the center of the plates $(n=$ 12 per genotype tested). Sample plates were incubated in the dark at $12^{\circ} \mathrm{C}$ and every 2 or 3 days after the transfer until 28 days after the initial transfer, two plates of each isolate were harvested. The ARI was determined for each plate. The weight of the culture was determined by weighing the total mycelium plus cellophane and initial transfer plug and subtracting the weight of the cellophane plus initial transfer plug. ARI was expressed as a function of the fresh weight of the culture for each genotype to determine the ARI at which no growth occurred. This threshold was used as an indication to determine qualitatively if cultures were alive.

Determination of developmental stage of sporangia on mycelial plugs after transfer from parent cultures. Because the objective of the experiment was to determine the influence of duration of exposure of temperatures less than $0^{\circ} \mathrm{C}$ on mycelial survival, it was necessary to determine the length of time for all sporangia to germinate after transfer of mycelial plugs from parent cultures. $P$. infestans cultures of each genotype were grown on SFCRA for 14 days in the dark at $12^{\circ} \mathrm{C}$. Ten 5 -mm-diameter cores were removed from the growing edge of each of 10 plates. The cores were placed into $10 \mathrm{ml}$ of $\mathrm{dH}_{2} \mathrm{O}$ in test tubes and stirred on a magnetic stirrer for $1 \mathrm{~h}$ to dislodge sporangia. The suspension was strained through four layers of cheesecloth, and the concentration of sporangia was calculated with a hemacytometer. The number of nongerminated and germinated sporangia was counted at the time of transfer and again 2 days after incubation at $4{ }^{\circ} \mathrm{C}$. After 2 days only empty sporangia were observed in any of the genotypes tested and a pretreatment of 2 days incubation at $4^{\circ} \mathrm{C}$ in the dark was imposed on all freshly transferred cores prior to exposure to temperature treatments.

Temperature exposure studies. Experiment $A$. The first set of temperature exposure experiments were done over a 24 -h period.

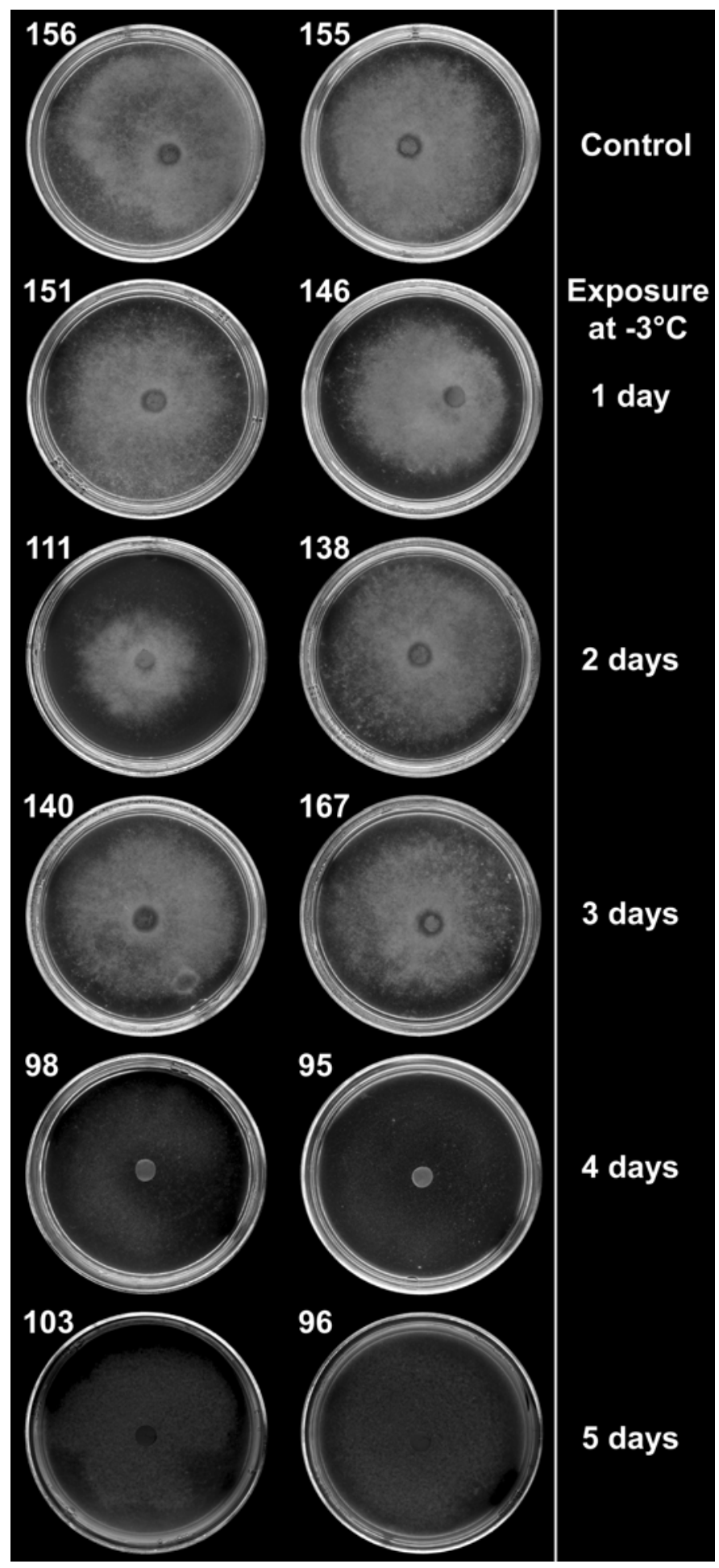

Fig. 1. Images of US8 genotype of Phytophthora infestans on sterol-free clarified rye agar plates exposed to $-3^{\circ} \mathrm{C}$ for $1,2,3,4$, and 5 days (top to bottom in pairs) and then incubated at $12^{\circ} \mathrm{C}$ for 28 days. The images at the top are the control plates exposed to $12^{\circ} \mathrm{C}$ for 5 days and incubated as treatments. The values are the average reflective intensities (ARI) in light intensity units (LIU) as measured with Sigma Scan. Plates with no detectable growth of mycelium had ARI values of less than 100 LIU. 
Fifty plates of each genotype and 50 noninoculated control plates were prepared 2 days prior to introduction to the temperature treatment. An additional 50 plates of each genotype was prepared and incubated in light at $12^{\circ} \mathrm{C}$ at the start of each experiment to serve as positive controls for the statistical analyses. The plates were labeled with culture ID numbers and exposure times, bound with Parafilm, placed together on a plastic loading tray, and then transferred to a PTC-1 Peltier-effect temperature cabinet (PTC-1) controlled by a PELT-3 Peltier-effect temperature controller (PELT3) (Sable Systems International, Henderson, NV). The PTC-1 chambers were positioned in $1.8 \mathrm{~m}^{3}$ temperature-controlled environment chambers (Environmental Growth Chambers, Chagrin Falls, $\mathrm{OH}$ ) at $5^{\circ} \mathrm{C}$. The PELT-3 was set for the exposure temperature $2 \mathrm{~h}$ prior to the start of the experiment. The tray with the culture plates was placed into the PTC-1 chambers quickly to minimize temperature increase. Temperature equilibration was measured after the door of the chamber was opened, and at $0^{\circ} \mathrm{C}$ set temperature, temperature rose to $5^{\circ} \mathrm{C}$ after the door was opened but then dropped to $-0.3^{\circ} \mathrm{C}$ in $1.5 \mathrm{~h}$. At $-3,-5,-10$, and $-20^{\circ} \mathrm{C}$ set temperatures, temperature rose to $-1.2,-1.5,-3.5$, and $-4.8^{\circ} \mathrm{C}$ and recovered in $1.1,1.3,1.5$, and $1.4 \mathrm{~h}$, respectively. Exposure times were measured from when the set temperature was reached.

Plates were removed after exposures of $1,4,8,12$, and $24 \mathrm{~h}$. Temperature treatments were $0,-3,-5,-10$, and $-20^{\circ} \mathrm{C}$. After plates were removed from the PTC- 1 cabinet, they were stored in the light at $12^{\circ} \mathrm{C}$. After 14 days, a sample (execution 1 of the experiment only) of five plates was scanned to determine the amount of growth of mycelium. The second set of plates $(n=5)$ was incubated at $12^{\circ} \mathrm{C}$ for 28 days prior to evaluation. The experiment was repeated twice from December 2000 to February 2001. The second and third executions of the experiment were evaluated 28 days after the temperature treatments.

Experiment $B$. The second set of temperature exposure experiments were done over a 5-day period. The experiment was set up as described previously, except plates were removed from the PTC-1 cabinet after exposures of 1, 2, 3, 4, and 5 days. Temperature treatments were $0,-3$, and $-5^{\circ} \mathrm{C}$. The experiment was repeated twice from March to April 2001. Plates were scanned after 28 days.

After regrowth of cultures, suspensions of zoosporangia were prepared from a subsample of two plates per genotype $(n=20)$ and temperature treatment and 10- $\mu$ l droplets were placed on the surface of each of five slices of sterilized cut potato tubers (cv. Atlantic). The tuber slices were placed on moist filter paper in petri dishes and incubated for 10 days at $12^{\circ} \mathrm{C}$ in growth chambers. If symptoms of necrotic tissue were noted spreading from the point of inoculation and sporangia could be observed on the infected tissue, it was concluded that the regrown cultures were viable.

Data analysis. The relation between the ARI and weight of individual cultures was determined by linear regression (SigmaStat version 2.03; Jandel Scientific, San Rafael, CA, and all subsequent analyses). Interactions between genotype, temperature, and period of exposure were determined by three-way analysis of vari- ance (ANOVA) for each execution of both experiments (A, 1-day and $\mathrm{B}, 5$-day maximum exposure). Repetitions were significantly different from the initial execution for both experiments (A, shortterm exposure up to 1 day $[F=15.4 ; P<0.001]$ and $\mathrm{B}$, long-term exposure up to 5 days $[F=10.6 ; P<0.001]$ ) and consequently each of the executions was analyzed separately for both experiments. Significant effects and interactions between genotype, temperature, and period of exposure were determined by three-way ANOVA for each repetition. Significant effects of genotype (except execution 2, 5-day exposure), temperature, and period of exposure were determined for both experiments (A, 1-day and B, 5-day maximum exposure [Table 1]). Consequently, two-way ANOVA was used to determine if recovery of colonies of $P$. infestans occurred from exposure period at each temperature within individual genotypes by comparing, at $P=0.05$, the ARI of the treated samples with the positive and negative controls grown at $12^{\circ} \mathrm{C}$ for comparable periods to determine the relative degree of survival. Combining these comparative outcomes resulted in a qualitative measure of survival; if the ARI of a sample was not significantly different (NSD) at $P=0.05$ from the negative control, the culture was considered dead (D); if NSD from the positive control, the culture was considered unaffected by either temperature treatment or exposure period (A); and if significantly different from both the negative and positive controls, the culture was considered affected by the treatment but not killed (I). Combinations of the possible outcomes of both temperature treatment and exposure period for repetitions of both experiments are shown in Table 2. The outcome of each treatment from the analyses of the three replicate experiments was quantified by assigning a value of 0 to $D, 1$ to $I$, and 2 to $A$, which were then summed and assigned to the treatment (Table 2). The qualitative outcome of temperature treatments and exposure periods was interpreted within and between the tested genotypes of $P$. infestans according to the definitions in Table 2.

TABLE 2. Index used to determine recovery potential of cultures of Phytophthora infestans exposed to temperatures for different periods

\begin{tabular}{|c|c|c|}
\hline Index & Qualitative statement of survival & $\begin{array}{l}\text { Possible combinations } \\
\text { of outcomes from } \\
\text { statistical analyses }\end{array}$ \\
\hline 0 & All sar & DDD \\
\hline 1 & Most & IDD \\
\hline 2 & Samples show tendency not to survive & IID, ADD \\
\hline 3 & $\begin{array}{l}\text { Samples show intermediate degree } \\
\text { of survival }\end{array}$ & III, IAD \\
\hline 4 & Samples show tendency to survive & IIA, A \\
\hline 5 & Most s & \\
\hline 6 & All samples alive & AAA \\
\hline \multicolumn{3}{|c|}{$\begin{array}{l}\mathrm{z} \mathrm{D}=\text { not significantly different from negative control; } \mathrm{I}=\text { significantl } \\
\text { different from negative control and positive control; } \mathrm{A}=\text { not significantl } \\
\text { different from positive control (all at } P=0.05 \text { ). Different outcomes fron } \\
\text { the analyses of the two repeats of the experiments are quantified by } \\
\text { assigning a value of } 0 \text { to } \mathrm{D}, 1 \text { to } \mathrm{I} \text {, and } 2 \text { to } \mathrm{A} \text {. The outcomes are totaled fo } \\
\text { each of the three executions of the experiments and the index numbe } \\
\text { assigned to the treatment. }\end{array}$} \\
\hline
\end{tabular}

TABLE 1. Sources of variation and their statistical significance for executions of two experiments to determine recovery of cultures of Phytophthora infestans exposed to temperatures for different periods

\begin{tabular}{|c|c|c|c|c|c|c|c|}
\hline \multirow{2}{*}{$\begin{array}{l}\text { Experiment } \\
\text { description }\end{array}$} & \multirow{2}{*}{$\begin{array}{l}\text { Source of } \\
\text { Variation }\end{array}$} & \multicolumn{2}{|c|}{ Execution 1} & \multicolumn{2}{|c|}{ Execution 2} & \multicolumn{2}{|c|}{ Execution 2} \\
\hline & & $F$ & $P$ & $F$ & $P$ & $F$ & $P$ \\
\hline \multirow[t]{3}{*}{ A: 1-day } & Genotype & 114.0 & $<0.001$ & 40.6 & $<0.001$ & 20.3 & $<0.001$ \\
\hline & Temperature & 760.0 & $<0.001$ & 74.0 & $<0.001$ & 278.6 & $<0.001$ \\
\hline & Exposure period & 43.7 & $<0.001$ & 58.1 & $<0.001$ & 163.0 & $<0.001$ \\
\hline \multirow[t]{3}{*}{ B: 5-day } & Genotype & 3.1 & 0.028 & 1.4 & 0.25 & 5.8 & $<0.001$ \\
\hline & Temperature & 194.5 & $<0.001$ & 156.9 & $<0.001$ & 164.5 & $<0.001$ \\
\hline & Exposure period & 80.5 & $<0.001$ & 78.2 & $<0.001$ & 118.9 & $<0.001$ \\
\hline
\end{tabular}




\section{RESULTS}

Relation of digital image of samples to weight of mycelium. Images of genotype US8 of $P$. infestans on SFCRA plates exposed to $-3^{\circ} \mathrm{C}$ for $1,2,3,4$, and 5 days (Fig. 1 , top to bottom in pairs) and then incubated at $12^{\circ} \mathrm{C}$ for 28 days are shown in Figure 1. In this example, the colonies recovered after up to 3 days exposure. ARI of samples increased directly with fresh weight of mycelium harvested over a 28-day period for each genotype (Fig. 2). The correlation coefficients of ARI expressed as a function of fresh weight were $r^{2}>0.8$ for individual genotypes, and intercepts, where fresh weight $=0.0 \mathrm{~g}$, were close to $100 \mathrm{LIU}$. The ARI values of agar plates that were inoculated with agar plugs with no mycelium of $P$. infestans ranged from 80 to 100 LIU in all experiments.

Temperature studies. Experiment A: treatment up to $24 h$; temperatures from -20 to $0^{\circ} \mathrm{C}$. The effects of genotype, temperature, and exposure period and their interactions on ARI were significant at $P=0.05$ (Table 1). Significant differences were also measured among repetitions of the experiments, and individual executions were analyzed separately. An example of the response of the four genotypes to exposure to temperatures from -20 to $0^{\circ} \mathrm{C}$ from 1 to $24 \mathrm{~h}$ is shown in Figure 3. A similar recovery pattern was observed in all executions of the experiment; at -20 and

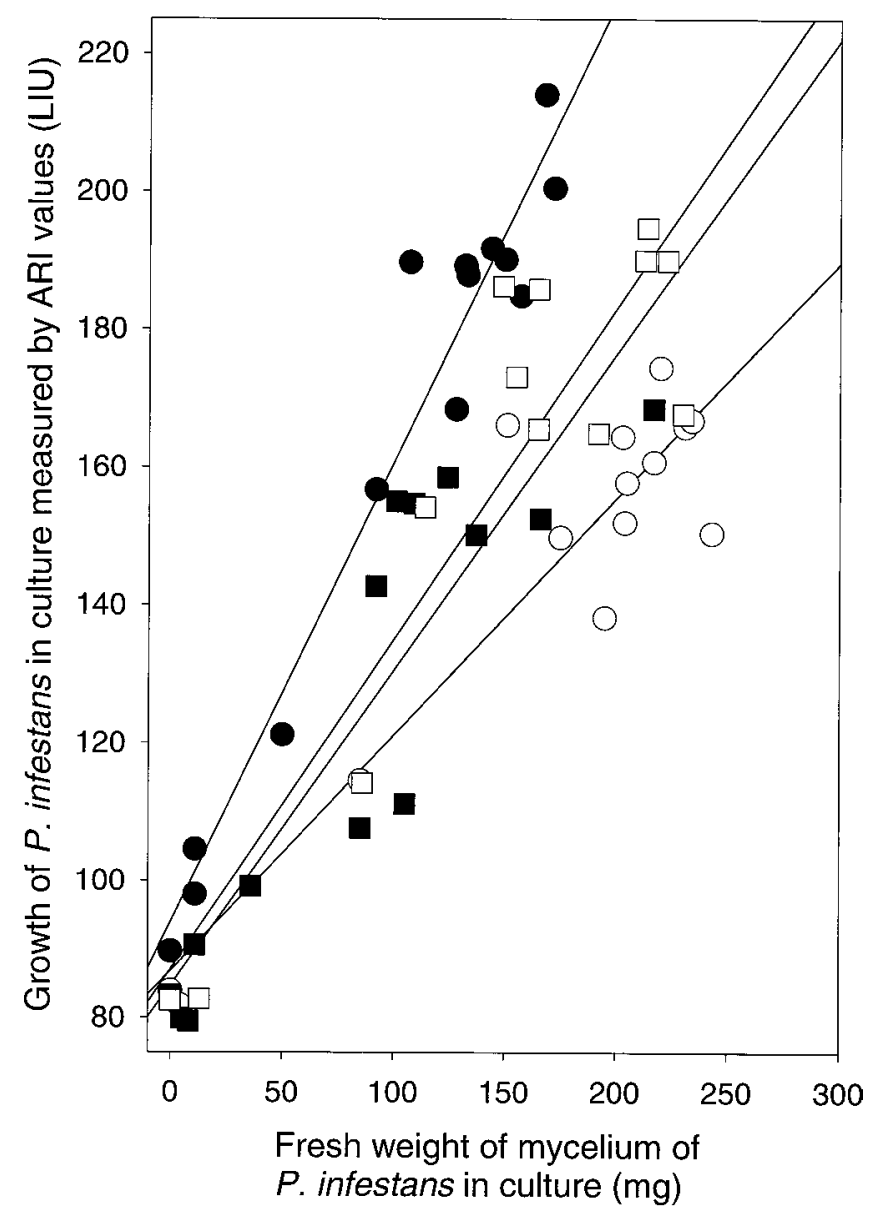

Fig. 2. The relation between fresh weight of mycelium and average reflective intensity (ARI) of cultures of different genotypes of Phytophthora infestans grown on cellophane-covered clarified rye agar on 40-mm-diameter petri dishes. Values represent ARI in light intensity units (LIU) as measured with Sigma Scan. Plates with no detectable growth of mycelium had ARI values of less than 100 LIU. The regression equations are as follows and $W$ represents the fresh weight of the culture: $\bullet=$ US1, ARI $=93.9+$ $0.67 \mathrm{~W}\left(r^{2}=0.95\right) ; \mathrm{O}=\mathrm{US} 8, \mathrm{ARI}=86.8+0.34 \mathrm{~W}\left(r^{2}=0.86\right) ; \square=\mathrm{US} 11$, $\mathrm{ARI}=84.6+0.46 \mathrm{~W}\left(r^{2}=0.82\right)$; and $\boldsymbol{\square}=\mathrm{US} 14$, ARI $=87.0+0.48 \mathrm{~W}$ $\left(r^{2}=0.85\right)$. $-10^{\circ} \mathrm{C}$, ARI values of all treatments were always similar to the negative control and ARI increased at warmer treatments, indicating recovery. The responses are shown in full in Table 3, which also indicates where the repetitions were different. Indices of survival at $-20^{\circ} \mathrm{C}$ for all genotypes were close to 0 although US 1 , US8, and US14 had indices of 1 at 1 -h exposure. At $-10^{\circ} \mathrm{C}$, the survival index of US1 was close to 0 but the other genotypes had higher indices, especially after short duration temperature treatments. Genotype US14 had higher indices than the other genotypes at treatments of up to $8 \mathrm{~h}$, indicating better recovery, but at 12 and $24 \mathrm{~h}$, all genotypes had indices close to 0 . The indices increased in all genotypes at $-5^{\circ} \mathrm{C}$ for most exposure periods, except $24 \mathrm{~h}$, and US8 and US14 had higher comparative indices than US1 and US11 at most thermal treatment periods. The indices at $-3^{\circ} \mathrm{C}$ tended to be higher for US1 and US11 than comparative treatments at $-5^{\circ} \mathrm{C}$. The indices remained similar for US8 and US14 genotypes, although at some exposure periods the index decreased. At $0^{\circ} \mathrm{C}$, all genotypes had indices of 6 , the same as the positive control.

Experiment $B$ : treatment up to 5 days; temperature from -5 to $O^{\circ} \mathrm{C}$. The effects of genotype, temperature, and exposure period and their interactions on ARI were significant at $P=0.05$ (Table 1 ). Response of the four genotypes to exposure at temperatures from -5 to $0^{\circ} \mathrm{C}$ from 1 to 5 days is shown in Figure 4 . The trend

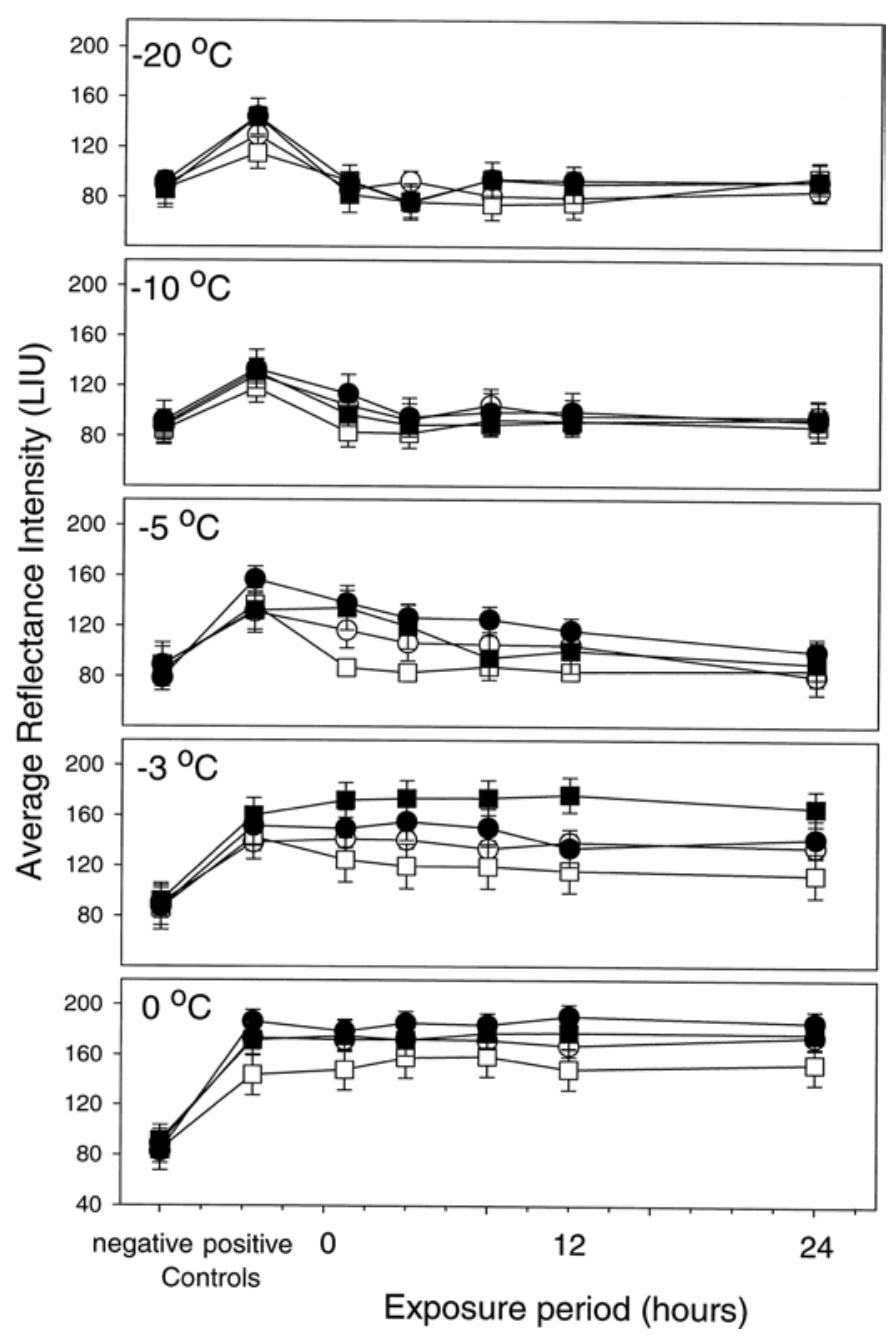

Fig. 3. Example of survival response (average reflective intensity execution 1, experiment A) of different genotypes of Phytophthora infestans exposed to temperatures from -20 to $0^{\circ} \mathrm{C}$ for different periods of time up to $24 \mathrm{~h}$ after incubation at $12^{\circ} \mathrm{C}$ for 4 weeks after exposure. US1 $=\square$; US8 $=\bullet$; US11 = $\mathrm{O}$; US14 = and the error bars represent $\mathrm{LSD}_{0.05}$ for comparisons of exposure periods within genotypes. 
was similar in each execution of the experiment; survival was not observed at $-5^{\circ} \mathrm{C}$ at any treatment period; at $-3^{\circ} \mathrm{C}$, ARI decreased with exposure period; and at $0^{\circ} \mathrm{C}$, ARI was not significantly different from the positive control. In detail, US14 had indices of 1 at $-5^{\circ} \mathrm{C}$ after $1,2,3$, and 4 days and 0 at 5 days (Table 4 ), but all other genotypes had indices of 0 at all exposure periods at $-5^{\circ} \mathrm{C}$. At $-3^{\circ} \mathrm{C}$, US1 had indices of 3,3 , and 2 after 1,2 , and 3 days, respectively, but indices of 0 at 4 and 5 days; US8 had indices of 6,5 , and 2 at 1,2 , and 3 days, respectively, but indices of 0 at 4 and 5 days; US11 had indices of 6 and 3 at 1 and 2 days, respectively, but indices of 0 at 3, 4, and 5 days; and US14 had indices of 3 at 1 to 5 days. All genotypes had indices of 6 at $0^{\circ} \mathrm{C}$ regardless of treatment exposure, the same as the positive control.

All cultures from both experiments were determined to be viable after regrowth because fresh spreading necrotic lesions and sporulation were observed on all inoculated tuber slices.

\section{DISCUSSION}

All genotypes of $P$. infestans tested in this study survived for up to 5 days at $0^{\circ} \mathrm{C}$ and showed an intermediate degree of survival for at least up to 3 days at $-3^{\circ} \mathrm{C}$. US14 genotype, although not consistently, showed a general tendency to survive at all exposure periods tested at $-3^{\circ} \mathrm{C}$ and was not always killed at $-5^{\circ} \mathrm{C}$. De Bruyn (7) showed that a mycelial colony was capable of withstanding $-25^{\circ} \mathrm{C}$ for up to 5 days in manure-based substrate and survival at such low temperatures was enhanced in dried sub-

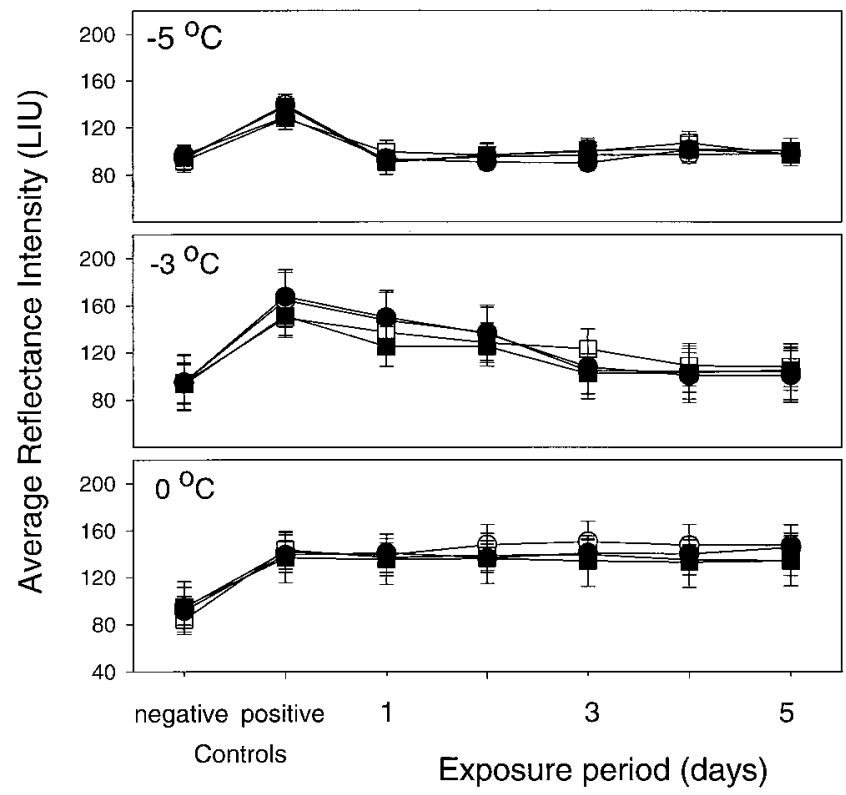

Fig. 4. Example of survival response (average reflective intensity execution 1 , experiment B) of different genotypes of Phytophthora infestans exposed to temperatures from -5 to $0^{\circ} \mathrm{C}$ for different periods of time up to 5 days after incubation at $12^{\circ} \mathrm{C}$ for 4 weeks after exposure. US1 $=\square$; US8 $=\bullet$; $\mathrm{US} 11=\mathrm{O}$; US14 $=\mathbf{\square}$ and the error bars represent $\mathrm{LSD}_{0.05}$ for comparisons of exposure periods within genotypes.

TABLE 3. Survival of different genotypes of Phytophthora infestans exposed to temperatures from -20 to $0^{\circ} \mathrm{C}$ for periods up to $24 \mathrm{~h}$ after incubation at $12^{\circ} \mathrm{C}$ for 4 weeks after exposure

\begin{tabular}{|c|c|c|c|c|c|c|c|c|c|c|c|c|c|c|c|c|c|c|c|c|c|}
\hline \multirow{3}{*}{$\begin{array}{l}\text { Isolate } \\
\text { identification }{ }^{\mathrm{w}}\end{array}$} & \multirow{3}{*}{$\begin{array}{l}\text { Exposure } \\
\text { time }^{\mathrm{x}}\end{array}$} & \multicolumn{20}{|c|}{ Significance categories for each execution and final survival index ${ }^{y}$} \\
\hline & & \multicolumn{20}{|c|}{ Exposure temperature $\left({ }^{\circ} \mathrm{C}\right)$} \\
\hline & & \multicolumn{4}{|c|}{-20} & \multicolumn{4}{|c|}{-10} & \multicolumn{4}{|c|}{-5} & \multicolumn{4}{|c|}{-3} & \multicolumn{4}{|c|}{0} \\
\hline US1 & Neg. control & $\mathrm{b}$ & $\mathrm{b}$ & $\mathrm{b}$ & 0 & $\mathrm{~b}$ & $\mathrm{c}$ & $\mathrm{b}$ & 0 & $\mathrm{c}$ & $\mathrm{b}$ & de & 0 & $\mathrm{~b}$ & $\mathrm{~d}$ & $\mathrm{~b}$ & 0 & $\mathrm{~b}$ & $\mathrm{~b}$ & $\mathrm{~b}$ & 0 \\
\hline A1 & Pos. control & $\mathrm{a}$ & $\mathrm{a}$ & $\mathrm{a}$ & 6 & $\mathrm{a}$ & $\mathrm{a}$ & $\mathrm{a}$ & 6 & $\mathrm{a}$ & $\mathrm{a}$ & $\mathrm{a}$ & 6 & $\mathrm{a}$ & $\mathrm{a}$ & $\mathrm{a}$ & 6 & $\mathrm{a}$ & $\mathrm{a}$ & $\mathrm{a}$ & 6 \\
\hline \multirow[t]{2}{*}{ MI95-6 } & 1 & $\mathrm{~b}$ & $\mathrm{~b}$ & $\mathrm{~b}$ & 1 & $\mathrm{~b}$ & $\mathrm{~b}$ & $\mathrm{~b}$ & 1 & $\mathrm{a}$ & $\mathrm{a}$ & $a b$ & 6 & $\mathrm{a}$ & $\mathrm{a}$ & $\mathrm{b}$ & 4 & $\mathrm{a}$ & a & a & 6 \\
\hline & 24 & $\mathrm{~b}$ & $\mathrm{~b}$ & $\mathrm{~b}$ & 0 & $\mathrm{~b}$ & $\mathrm{c}$ & $\mathrm{b}$ & 0 & $\mathrm{c}$ & $\mathrm{b}$ & $\mathrm{e}$ & 0 & $\mathrm{a}$ & $\mathrm{c}$ & $\mathrm{b}$ & 3 & $\mathrm{a}$ & $\mathrm{a}$ & $\mathrm{a}$ & 6 \\
\hline US8 & Neg. control & $\mathrm{b}$ & $\mathrm{c}$ & $\mathrm{b}$ & 0 & $\mathrm{c}$ & $\mathrm{d}$ & $\mathrm{bc}$ & 0 & $\mathrm{f}$ & $\mathrm{d}$ & $\mathrm{d}$ & 0 & $\mathrm{c}$ & $\mathrm{c}$ & $\mathrm{d}$ & 0 & $\mathrm{~b}$ & $\mathrm{~b}$ & $\mathrm{~b}$ & 0 \\
\hline A2 & Pos. control & $\mathrm{a}$ & $\mathrm{a}$ & $\mathrm{a}$ & 6 & $\mathrm{a}$ & $\mathrm{a}$ & $\mathrm{a}$ & 6 & $\mathrm{a}$ & $a b$ & $a b$ & 6 & $\mathrm{a}$ & $\mathrm{a}$ & $\mathrm{a}$ & 6 & $\mathrm{a}$ & $\mathrm{a}$ & $\mathrm{a}$ & 6 \\
\hline \multirow[t]{3}{*}{ MI95-7 } & 1 & $\mathrm{~b}$ & $\mathrm{c}$ & $\mathrm{b}$ & 0 & $\mathrm{~b}$ & $\mathrm{~b}$ & $\mathrm{a}$ & 4 & $\mathrm{~b}$ & $\mathrm{bc}$ & $\mathrm{b}$ & 5 & $\mathrm{a}$ & $\mathrm{b}$ & $\mathrm{b}$ & 4 & $\mathrm{a}$ & $\mathrm{a}$ & $\mathrm{a}$ & 6 \\
\hline & 4 & $\mathrm{~b}$ & $\mathrm{c}$ & $\mathrm{b}$ & 0 & $\mathrm{c}$ & $\mathrm{b}$ & $\mathrm{b}$ & 1 & $\mathrm{c}$ & $\mathrm{c}$ & $a b$ & 4 & $\mathrm{a}$ & $a b$ & $\mathrm{~b}$ & 5 & $\mathrm{a}$ & $\mathrm{a}$ & $\mathrm{a}$ & 6 \\
\hline & 8 & $\mathrm{~b}$ & $\mathrm{c}$ & $\mathrm{b}$ & 0 & $\mathrm{bc}$ & $\mathrm{cd}$ & $\mathrm{bc}$ & 0 & $\mathrm{~cd}$ & $\mathrm{a}$ & $\mathrm{a}$ & 5 & $\mathrm{a}$ & $\mathrm{ab}$ & $\mathrm{bc}$ & 5 & $\mathrm{a}$ & a & $\mathrm{a}$ & 6 \\
\hline \multirow{4}{*}{ MI96-1 } & 4 & $\mathrm{c}$ & $\mathrm{b}$ & $\mathrm{bc}$ & 0 & $\mathrm{~b}$ & $\mathrm{c}$ & $\mathrm{b}$ & 0 & $\mathrm{~b}$ & $\mathrm{~b}$ & de & 1 & $\mathrm{~b}$ & $a b$ & $\mathrm{bc}$ & 4 & $\mathrm{a}$ & $\mathrm{a}$ & $\mathrm{a}$ & 6 \\
\hline & 8 & $\mathrm{c}$ & $\mathrm{b}$ & $\mathrm{c}$ & 0 & $\mathrm{~b}$ & $\mathrm{c}$ & $\mathrm{b}$ & 1 & $\mathrm{~b}$ & $\mathrm{~b}$ & $\mathrm{c}$ & 2 & $\mathrm{~b}$ & $\mathrm{bc}$ & $\mathrm{d}$ & 1 & $\mathrm{a}$ & $\mathrm{a}$ & $\mathrm{a}$ & 6 \\
\hline & 12 & $\mathrm{c}$ & $\mathrm{b}$ & $\mathrm{bc}$ & 0 & $\mathrm{~b}$ & $\mathrm{c}$ & $\mathrm{b}$ & 0 & $\mathrm{~b}$ & $\mathrm{~b}$ & $\mathrm{c}$ & 2 & $\mathrm{~b}$ & $\mathrm{bc}$ & d & 1 & $\mathrm{a}$ & $\mathrm{a}$ & $\mathrm{a}$ & 6 \\
\hline & 24 & $\mathrm{~b}$ & $\mathrm{~b}$ & $\mathrm{~b}$ & 0 & $\mathrm{~b}$ & $a-c$ & $\mathrm{~b}$ & 1 & $\mathrm{~b}$ & $\mathrm{~b}$ & $\mathrm{~d}$ & 1 & $\mathrm{~b}$ & $\mathrm{c}$ & $\mathrm{cd}$ & 1 & $\mathrm{a}$ & $\mathrm{a}$ & $\mathrm{a}$ & 6 \\
\hline US14 & Neg. control & $\mathrm{c}$ & $\mathrm{b}$ & $\mathrm{c}$ & 0 & $\mathrm{c}$ & $\mathrm{c}$ & $\mathrm{cd}$ & 0 & $\mathrm{c}$ & $\mathrm{b}$ & $\mathrm{e}$ & 0 & $\mathrm{~b}$ & $\mathrm{c}$ & $\mathrm{c}$ & 0 & $\mathrm{~b}$ & $\mathrm{~b}$ & $\mathrm{~b}$ & 0 \\
\hline A2 & Pos. control & $\mathrm{a}$ & $\mathrm{a}$ & $\mathrm{a}$ & 6 & $\mathrm{a}$ & $\mathrm{a}$ & $\mathrm{a}$ & 6 & $\mathrm{a}$ & $\mathrm{a}$ & $\mathrm{c}$ & 6 & $\mathrm{a}$ & $\mathrm{a}$ & $\mathrm{a}$ & 6 & $\mathrm{a}$ & $\mathrm{a}$ & $\mathrm{a}$ & 6 \\
\hline \multirow[t]{5}{*}{ WA671 } & 1 & $\mathrm{bc}$ & $\mathrm{b}$ & $\mathrm{c}$ & 0 & $\mathrm{~b}$ & $\mathrm{a}$ & $\mathrm{b}$ & 4 & $\mathrm{~b}$ & $\mathrm{a}$ & $a b$ & 5 & $\mathrm{a}$ & $\mathrm{b}$ & $\mathrm{b}$ & 4 & $\mathrm{a}$ & $\mathrm{a}$ & a & 6 \\
\hline & 4 & $\mathrm{~b}$ & $\mathrm{~b}$ & $\mathrm{bc}$ & 1 & $\mathrm{bc}$ & $\mathrm{a}$ & $\mathrm{c}$ & 2 & $\mathrm{~b}$ & $\mathrm{a}$ & $\mathrm{b}$ & 5 & $\mathrm{a}$ & $\mathrm{b}$ & $\mathrm{b}$ & 4 & $\mathrm{a}$ & $\mathrm{a}$ & $\mathrm{a}$ & 6 \\
\hline & 8 & $\mathrm{c}$ & $\mathrm{b}$ & $\mathrm{c}$ & 0 & $\mathrm{~b}$ & $\mathrm{~b}$ & $\mathrm{~cd}$ & 2 & $\mathrm{~b}$ & $\mathrm{a}$ & $\mathrm{b}$ & 5 & $\mathrm{a}$ & $\mathrm{b}$ & $\mathrm{b}$ & 4 & $\mathrm{a}$ & a & a & 6 \\
\hline & 12 & $\mathrm{c}$ & $\mathrm{b}$ & $\mathrm{bc}$ & 0 & $\mathrm{bc}$ & $\mathrm{b}$ & $\mathrm{d}$ & 1 & $\mathrm{~b}$ & $\mathrm{a}$ & $\mathrm{a}$ & 5 & $\mathrm{a}$ & $\mathrm{b}$ & $\mathrm{c}$ & 3 & $\mathrm{a}$ & $\mathrm{a}$ & $\mathrm{a}$ & 6 \\
\hline & 24 & $\mathrm{bc}$ & $\mathrm{b}$ & $\mathrm{c}$ & 0 & $\mathrm{bc}$ & $\mathrm{b}$ & $\mathrm{d}$ & 1 & $\mathrm{c}$ & $\mathrm{b}$ & $\mathrm{d}$ & 1 & $\mathrm{a}$ & $a b$ & $\mathrm{c}$ & 4 & $\mathrm{a}$ & $\mathrm{a}$ & $\mathrm{a}$ & 6 \\
\hline
\end{tabular}

${ }^{\mathrm{w}}$ Isolate identification listed as genotype (12), mating type (6), and laboratory identification code; e.g., MI95-7 represents sample seven isolated in Michigan in 1995; WA represents Washington State followed by code numbers for laboratory identification.

${ }^{\mathrm{x}}$ Exposure time (hours) of cultures to treatment temperatures. Neg. control = negative control (inoculated with mycelium-free agar plug, and exposed to $12^{\circ} \mathrm{C}$ for equivalent treatment, temperature, and exposure period before incubation). Pos. control = positive control (inoculated with agar plug plus mycelium and exposed to $12^{\circ} \mathrm{C}$ for equivalent treatment, temperature, and exposure period before incubation).

$y$ The values are the index numbers that indicate degree of survival as explained in Table 2.

${ }^{\mathrm{z}}$ The numbers refer to different executions of the experiment. Treatments sharing a common letter had mean average reflectance intensity not significantly different at $P=0.05$ (according to Tukey's multiple comparison). Analyses were conducted for each execution among treatments within combinations of genotype, temperature, and exposure period. 
strates (7). Although this result was of interest, in biological systems, temperatures close to $0^{\circ} \mathrm{C}$ are of greater importance ecologically than those around $-20^{\circ} \mathrm{C}$ because the environment may be tolerable for overwintering of host and pathogen. Supercooling of cells to $-20^{\circ} \mathrm{C}$ may involve a different mechanism than that involved in acclimatization (30). Temperature tolerance has ecological significance, especially in agricultural regions where the climate is warming and becoming more conducive for late blight (1). Since 1950, soils have become more likely to freeze in the Great Lakes region due to climate change, but only to a depth of $5 \mathrm{~cm}$ (15), which is above the depth that tubers may be buried. $P$. infestans can survive at $3^{\circ} \mathrm{C}$ within infected tubers as stored seed (22) but little is known about its survival in volunteer tubers returned to the soil after harvest. Reports of increased annual mean daily temperature in the Great Lakes region of the United States $(1,15)$ increases the potential for survival of volunteer potatoes in fields and cull piles $(1,21)$ possibly harboring inoculum of $P$. infestans (31). Because buried potato tubers are not frequently exposed to temperatures that normally cause substrate breakdown (about $-3^{\circ} \mathrm{C}$ ) (W. W. Kirk, unpublished data), the risk of blighted tubers surviving winter in field settings also increases. The apparent increased tolerance of US8 and US14 genotypes of $P$. infestans reported in this study to lower temperatures is cause for concern. Further work is needed to address this problem.

Tolerance to temperatures ranging from 0 to $-3^{\circ} \mathrm{C}$ and the continued use of foliar applications of mefenoxam in potatoes for control of tuber disease such as pink rot, caused by P. erythro- septica (29), in spite of mefenoxam resistance in $P$. infestans, may have contributed to the predominance of the mefenoxam-tolerant genotypes such as US8 in Midwestern potato production areas. Different genotypes of $P$. infestans vary in aggressiveness in foliar infections $(20,23)$. This study suggests that the US8 genotype is more tolerant of temperatures close to $0^{\circ} \mathrm{C}$ and may be an additional factor contributing to the displacement of the US1 genotype predominant in the United States prior to $1994(11,14)$. The US11 genotype has been found quite frequently in mild maritime climates (10) such as Washington $(8,16)$ but infrequently in other regions perhaps due to its reduced tolerance of colder temperatures.

The digital method of assessment of survival of mycelium of $P$. infestans in vitro is based on light reflectance from developing mycelium. Image analysis is quantitative and objective and scanned images can be stored for future comparisons (22).

The relationship between ARI and mycelium weight was direct and established ARI as a good estimation of survival of the temperature-exposed cultures. Radial growth of mycelium on plates may overestimate survival potential especially if the mycelium is growing sparsely. Growth of marginally surviving cultures may spread to the edge of the plate and be measured as maximum diameter and would have the same value as a dense and vigorous culture, perhaps overestimating the recovery of the challenged culture. Although quantification and comparison of the degree of survival were not attempted among treatments in this study, it is clear from the images that quantitative interpretation of treat-

TABLE 4. Survival of isolates of different genotypes of Phytophthora infestans exposed to temperatures from -5 to $0^{\circ} \mathrm{C}$ for periods up to 5 days measured as average reflective intensity (ARI) of images of cultures incubated for 4 weeks at $12^{\circ} \mathrm{C}$ after exposure

\begin{tabular}{|c|c|c|c|c|c|c|c|c|c|c|c|c|c|}
\hline \multirow{4}{*}{$\begin{array}{l}\text { Isolate } \\
\text { identification }^{\mathrm{w}}\end{array}$} & \multirow{4}{*}{$\begin{array}{l}\text { Exposure } \\
\text { time }^{\mathrm{x}}\end{array}$} & \multicolumn{11}{|c|}{ Significance categories for each execution and final survival index ${ }^{y}$} & \\
\hline & & \multicolumn{12}{|c|}{ Exposure temperature $\left({ }^{\circ} \mathrm{C}\right)$} \\
\hline & & \multicolumn{4}{|c|}{-5} & \multicolumn{4}{|c|}{-3} & \multicolumn{4}{|c|}{0} \\
\hline & & $1^{\mathrm{z}}$ & $2^{\mathrm{z}}$ & $3^{z}$ & $\mathrm{I}^{\mathrm{y}}$ & 1 & 2 & 3 & I & 1 & 2 & 3 & I \\
\hline$\overline{\text { US1 }}$ & Neg. control & $\mathrm{b}$ & $\mathrm{b}$ & $\mathrm{b}$ & 0 & $\mathrm{c}$ & $\mathrm{c}$ & $\mathrm{c}$ & 6 & $\mathrm{~b}$ & $\mathrm{~b}$ & $\mathrm{~b}$ & 0 \\
\hline A1 & Pos. control & $\mathrm{a}$ & a & $\mathrm{a}$ & 6 & $\mathrm{a}$ & $\mathrm{a}$ & $\mathrm{a}$ & 0 & $\mathrm{a}$ & $\mathrm{a}$ & $\mathrm{a}$ & 6 \\
\hline \multirow[t]{5}{*}{ MI95-6 } & 1 & $\mathrm{~b}$ & $\mathrm{~b}$ & $\mathrm{~b}$ & 0 & $\mathrm{~b}$ & $\mathrm{a}$ & $\mathrm{a}$ & 3 & $\mathrm{a}$ & $\mathrm{a}$ & $\mathrm{a}$ & 6 \\
\hline & 2 & $\mathrm{~b}$ & $\mathrm{~b}$ & $\mathrm{~b}$ & 0 & $\mathrm{~b}$ & $\mathrm{a}$ & $\mathrm{a}$ & 3 & $\mathrm{a}$ & $\mathrm{a}$ & $\mathrm{a}$ & 6 \\
\hline & 3 & $\mathrm{~b}$ & $\mathrm{~b}$ & $\mathrm{~b}$ & 0 & $\mathrm{c}$ & $\mathrm{b}$ & $\mathrm{b}$ & 2 & $\mathrm{a}$ & $\mathrm{a}$ & $\mathrm{a}$ & 6 \\
\hline & 4 & $\mathrm{~b}$ & $\mathrm{~b}$ & $\mathrm{~b}$ & 0 & $\mathrm{c}$ & $\mathrm{c}$ & $\mathrm{c}$ & 0 & $\mathrm{a}$ & $\mathrm{a}$ & $\mathrm{a}$ & 6 \\
\hline & 5 & $\mathrm{~b}$ & $\mathrm{~b}$ & $\mathrm{~b}$ & 0 & $\mathrm{c}$ & $\mathrm{c}$ & $\mathrm{c}$ & 0 & $\mathrm{a}$ & $\mathrm{a}$ & $\mathrm{a}$ & 6 \\
\hline US8 & Neg. control & $\mathrm{b}$ & $\mathrm{b}$ & $\mathrm{b}$ & 0 & $\mathrm{c}$ & $\mathrm{c}$ & $\mathrm{c}$ & 6 & $\mathrm{~b}$ & $\mathrm{~b}$ & $\mathrm{~b}$ & 0 \\
\hline A2 & Pos. control & $\mathrm{a}$ & $\mathrm{a}$ & $\mathrm{a}$ & 6 & $\mathrm{a}$ & $\mathrm{a}$ & $\mathrm{a}$ & 0 & $\mathrm{a}$ & $\mathrm{a}$ & $\mathrm{a}$ & 6 \\
\hline \multirow[t]{5}{*}{ MI95-7 } & 1 & $\mathrm{~b}$ & $\mathrm{~b}$ & $\mathrm{~b}$ & 0 & $\mathrm{a}$ & $\mathrm{a}$ & $\mathrm{a}$ & 6 & $\mathrm{a}$ & $\mathrm{a}$ & $\mathrm{a}$ & 6 \\
\hline & 2 & $\mathrm{~b}$ & $\mathrm{~b}$ & $\mathrm{~b}$ & 0 & $a b$ & $\mathrm{a}$ & $a b$ & 5 & $\mathrm{a}$ & $\mathrm{a}$ & $\mathrm{a}$ & 6 \\
\hline & 3 & $\mathrm{~b}$ & $\mathrm{~b}$ & $\mathrm{~b}$ & 0 & $\mathrm{c}$ & $\mathrm{b}$ & $\mathrm{b}$ & 2 & $\mathrm{a}$ & $\mathrm{a}$ & $\mathrm{a}$ & 6 \\
\hline & 4 & $\mathrm{~b}$ & $\mathrm{~b}$ & $\mathrm{~b}$ & 0 & $\mathrm{c}$ & $\mathrm{c}$ & $\mathrm{c}$ & 0 & $\mathrm{a}$ & $\mathrm{a}$ & $\mathrm{a}$ & 6 \\
\hline & 5 & $\mathrm{~b}$ & $\mathrm{~b}$ & $\mathrm{~b}$ & 0 & $\mathrm{c}$ & $\mathrm{c}$ & $\mathrm{c}$ & 0 & $\mathrm{a}$ & $\mathrm{a}$ & $\mathrm{a}$ & 6 \\
\hline US11 & Neg. control & $\mathrm{b}$ & $\mathrm{b}$ & $\mathrm{b}$ & 0 & $\mathrm{c}$ & $\mathrm{c}$ & $\mathrm{c}$ & 6 & $\mathrm{~b}$ & $\mathrm{~b}$ & $\mathrm{~b}$ & 0 \\
\hline A1 & Pos. control & $\mathrm{a}$ & $\mathrm{a}$ & $\mathrm{a}$ & 6 & $\mathrm{a}$ & $\mathrm{a}$ & $\mathrm{a}$ & 0 & $\mathrm{a}$ & $\mathrm{a}$ & $\mathrm{a}$ & 6 \\
\hline \multirow[t]{5}{*}{ MI96-1 } & 1 & $\mathrm{~b}$ & $\mathrm{~b}$ & $\mathrm{~b}$ & 0 & $a b$ & $\mathrm{a}$ & $\mathrm{a}$ & 6 & $\mathrm{a}$ & $\mathrm{a}$ & $\mathrm{a}$ & 6 \\
\hline & 2 & $\mathrm{~b}$ & $\mathrm{~b}$ & $\mathrm{~b}$ & 0 & $\mathrm{~b}$ & $\mathrm{~b}$ & $\mathrm{~b}$ & 3 & $\mathrm{a}$ & $\mathrm{a}$ & $\mathrm{a}$ & 6 \\
\hline & 3 & $\mathrm{~b}$ & $\mathrm{~b}$ & $\mathrm{~b}$ & 0 & $\mathrm{c}$ & $\mathrm{c}$ & $\mathrm{c}$ & 0 & $\mathrm{a}$ & $\mathrm{a}$ & $\mathrm{a}$ & 6 \\
\hline & 4 & $\mathrm{~b}$ & $\mathrm{~b}$ & $\mathrm{~b}$ & 0 & $\mathrm{c}$ & $\mathrm{c}$ & $\mathrm{c}$ & 0 & $\mathrm{a}$ & $\mathrm{a}$ & $\mathrm{a}$ & 6 \\
\hline & 5 & $\mathrm{~b}$ & $\mathrm{~b}$ & $\mathrm{~b}$ & 0 & $\mathrm{c}$ & $\mathrm{c}$ & $\mathrm{c}$ & 0 & $\mathrm{a}$ & $\mathrm{a}$ & $\mathrm{a}$ & 6 \\
\hline US14 & Neg. control & $\mathrm{c}$ & $\mathrm{c}$ & $\mathrm{d}$ & 0 & $\mathrm{~d}$ & $\mathrm{c}$ & d & 6 & $\mathrm{~b}$ & $\mathrm{~b}$ & $\mathrm{~b}$ & 0 \\
\hline & Pos. control & $\mathrm{a}$ & $\mathrm{a}$ & $\mathrm{a}$ & 6 & $\mathrm{a}$ & $\mathrm{a}$ & $\mathrm{a}$ & 0 & $\mathrm{a}$ & $\mathrm{a}$ & $\mathrm{a}$ & 6 \\
\hline \multirow{5}{*}{ WA671 } & 1 & $\mathrm{bc}$ & $\mathrm{b}$ & $\mathrm{b}$ & 1 & $a b$ & $a b$ & $\mathrm{~b}$ & 3 & $\mathrm{a}$ & $\mathrm{a}$ & $\mathrm{a}$ & 6 \\
\hline & 2 & $\mathrm{c}$ & $\mathrm{bc}$ & $\mathrm{c}$ & 1 & $\mathrm{~b}$ & $a b$ & $a b$ & 3 & $\mathrm{a}$ & $\mathrm{a}$ & $\mathrm{a}$ & 6 \\
\hline & 3 & $\mathrm{bc}$ & $\mathrm{b}$ & $\mathrm{c}$ & 1 & $\mathrm{bc}$ & $\mathrm{b}$ & $\mathrm{b}$ & 3 & $\mathrm{a}$ & $\mathrm{a}$ & $\mathrm{a}$ & 6 \\
\hline & 4 & $\mathrm{~b}$ & $\mathrm{~b}$ & $\mathrm{c}$ & 1 & $\mathrm{~cd}$ & $\mathrm{c}$ & $\mathrm{c}$ & 3 & $\mathrm{a}$ & $\mathrm{a}$ & $\mathrm{a}$ & 6 \\
\hline & 5 & $\mathrm{c}$ & $\mathrm{bc}$ & $\mathrm{c}$ & 0 & $\mathrm{~cd}$ & $\mathrm{c}$ & $\mathrm{c}$ & 3 & $\mathrm{a}$ & $\mathrm{a}$ & $\mathrm{a}$ & 6 \\
\hline
\end{tabular}

${ }^{\mathrm{w}}$ Isolate identification listed as genotype (12), mating type (6), and laboratory identification code; e.g., MI95-7 represents sample seven isolated in Michigan in 1995; WA represents Washington State followed by code numbers for laboratory identification.

${ }^{\mathrm{x}}$ Exposure time (hours) of cultures to treatment temperatures. Neg. control = negative control (inoculated with mycelium-free agar plug, and exposed to $12^{\circ} \mathrm{C}$ for equivalent treatment, temperature, and exposure period before incubation). Pos. control = positive control (inoculated with agar plug plus mycelium and exposed to $12^{\circ} \mathrm{C}$ for equivalent treatment, temperature, and exposure period before incubation).

y The values are the index numbers that indicate degree of survival as explained in Table 2.

${ }^{\mathrm{z}}$ The numbers refer to different executions of the experiment. Treatments sharing a common letter had mean ARI not significantly different at $P=0.05$ (according to Tukey's multiple comparison). Analyses were conducted for each execution among treatments within combinations of genotype, temperature, and exposure period. 
ment effects is possible. In this study, only the difference from noninoculated plates after exposure to a range of temperatures for different durations was used as an indicator of survival of mycelium.

Although it is not possible to determine beyond doubt that some sporangia survived the pretreatments prior to temperature exposure, all steps to ensure minimal production of sporangia in the parent cultures were attempted, i.e., incubation in the dark at $12^{\circ} \mathrm{C}$ on sterol-free growth medium and then acclimatization for 2 days at $4{ }^{\circ} \mathrm{C}$ prior to exposure to the temperature treatment. Because only empty sporangia were detected after this pretreatment, it was concluded that the plugs exposed to the temperature treatments consisted only of mycelium. No germinating encysted zoospores were observed by microscopic investigations.

Further work on the tolerance of mycelium from a wider range of isolates of $P$. infestans representative of genotypes is underway to determine if this tolerance is typical of the genotypes that have largely replaced the clonal lineage (US1) found in North America prior to 1990. Because few commercial cultivars have substantive field resistance to foliar infection caused by US8 biotypes of $P$. infestans $(9,14)$, the potential for survival of mycelium in tubers and production of initial inoculum in succeeding years is ominous for potato production. The interaction between climate change and thermal tolerance of $P$. infestans may have profound effects for the future of potato production in the Great Lakes region and other northern regions of North America.

\section{ACKNOWLEDGMENTS}

This material was prepared with support from the Michigan Potato Industry Commission and with help from R. S. Shaw.

\section{LITERATURE CITED}

1. Baker, K. M., Kirk, W. W., Andresen, J. A., and Stein, J. M. A problem case study: Influence of climatic trends on late blight epidemiology in potatoes. Proc. 26th Int. Horticultural Congress and Exhibition (IHC2002). Acta Hortic. (In Press.)

2. Bollen, G. J. 1985. Lethal temperatures of soil fungi. Pages 191-193 in: Ecology and Management of Soilborne Plant Pathogens. A. D. R. C. A. Parker, K. J. Moore, P. T. W. Wong, and J. F. Kollmorgen, eds. The American Phytopathological Society, St. Paul, MN

3. Boyd, A. E. W. 1974. Sources of potato late blight (Phytophthora infestans) in the east of Scotland. Plant Pathol. 23:30-36.

4. Coelho, L., Mitchell, D. J., and Chellemi, D. O. 2000. Thermal inactivation of Phytophthora nicotianae. Phytopathology 90:1089-1097.

5. Davidse, L. C., Henken, J., van Dalen, A., Jespers, A. B. K., and Mantel, B. C. 1989. Nine years of practical experience with phenylamide resistance in Phytophthora infestans in the Netherlands. Neth. J. Plant Pathol. 95(suppl. 1):197-213.

6. Deahl, K. L., DeMuth, S. P., Sinder, S. L., and Revera-Pena, A. 1995. Identification of mating types and metalaxyl resistance in North American populations of Phytophthora infestans. Am. Potato J. 72:3550 .

7. De Bruyn, H. L. G. 1926. The overwintering of Phytophthora infestans (Mont.) de Bary. Phytopathology 16:121-140.

8. Derie, M. L., and Inglis, D. A. 2001. Persistence of complex virulences in populations of Phytophthora infestans in Western Washington. Phytopathology 91:606-612.

9. Douches, D. S., Kirk, W. W., Jastrzebski, K., Long, C., and Hammerschmidt, R. 1997. Susceptibility of potato varieties and advanced breeding lines (Solanum tuberosum $\mathrm{L}$ ) to Phytophthora infestans (Mont) de Bary in greenhouse screenings. Am. Potato J. 74:75-86.
10. Easton, G. D. 1982. Late blight of potatoes and prediction of epidemics in arid central Washington State. Plant Dis. 66:452-455.

11. Fry, W. E., and Goodwin, S. B. 1997. Re-emergence of potato and tomato late blight in the United States. Plant Dis. 81:1349-1357.

12. Goodwin, S. B., Schneider, R. E., and Fry, W. E. 1995. Use of celluloseacetate electrophoresis for rapid identification of allozyme genotypes of Phytophthora infestans. Plant Dis. 79:1181-1185.

13. Grinberger, M., Kadish, D., and Cohen, Y. 1995. Infectivity of metalaxyl-sensitive and metalaxyl-resistant isolates of Phytophthora infestans to whole potato tubers as affected by tuber aging and storage. Phytoparasitica 23:165-175.

14. Inglis, D. A., Johnson, D. A., Legard, D. E., Fry, W. E., and Hamm, P. B. 1996. Relative resistances of potato clones in response to new and old populations of Phytophthora infestans. Plant Dis. 80:575-578.

15. Isard, S. A., and Schaetzl, R. J. 1998. Effects of winter weather conditions on soil freezing in southern Michigan. Phys. Geo. 19:71-94.

16. Johnson, D. A. 1998. Expansion of potato late blight forecasting models for the Columbia Basin of Washington and Oregon. Plant Dis. 82:642645.

17. Johnson, D. A., Cummings, T. F., and Geary, B. 2000. Postinfection activity of selected late blight fungicides. Plant Dis. 84:1116-1120.

18. Juarez-Palacios, C., Felix-Gastelum, R., Wakeman, R. J., Paplomatas, E. J., and DeVay, J. E. 1991. Thermal sensitivity of three species of Phytophthora and the effect of soil solarization on their survival. Plant Dis. 75:1160-1164.

19. Kadish, D., and Cohen, Y. 1992. Over seasoning of metalaxyl-sensitive and metalaxyl-resistant isolates of Phytophthora infestans in potato tubers. Phytopathology 82:887-889.

20. Kato, M., Mizubuti, E. S., Goodwin, S. B., and Fry, W. E. 1997. Sensitivity to protectant fungicides and pathogenic fitness of clonal lineages of Phytophthora infestans in the United States. Phytopathology 87:973978.

21. Kirk, W. W. 2003. Thermal properties of over wintered potato cull piles. Am. J. Potato Res. 80:145-149.

22. Kirk, W. W., Niemira, B. A., and Stein, J. M. 2001. Influence of storage temperature on rate of potato tuber tissue infection caused by different biotypes of Phytophthora infestans (Mont.) de Bary estimated by digital image analysis. Potato Res. 44:86-96.

23. Lambert, D. H., and Currier, A. I. 1997. Differences in tuber rot development for North American clones of Phytophthora infestans. Am. Potato J. 74:39-43.

24. Lambert, D. H., Currier, A. I., and Olanya, M. O. 1998. Transmission of Phytophthora infestans in cut potato seed. Am. J. Potato Res. 75:257263.

25. Miller, J. S., and Johnson, D. A. 2000. Competitive fitness of Phytophthora infestans isolates under semiarid field conditions. Phytopathology 90:220-227.

26. Monteith, J. L. 1977. Climate and the efficiency of crop production in Britain. Phil. Trans. R. Soc. London B281:277-297.

27. Partpillo, H. M., Powelson, M. L., and Inglis, D. A. 2000. Seedborne Phytophthora infestans: Rate of transmission and effect on stand in five potato cultivars. Am. J. Potato Res. 77:415.

28. Powelson, M. L., and Inglis, D. A. 1999. Foliar fungicides as protective seed piece treatments for management of late blight of potatoes. Plant Dis. 83:265-268.

29. Secor, G. A., and Gudmestad, N. C. 1999. Managing fungal diseases of potato. Can. J. Plant Pathol. 21:212-221.

30. Snider, S. S., Hsiang, T., Zhao, G., and Griffith, M. 2000. Role of ice nucleation and antifreeze activities in pathogenesis and growth of snow molds. Phytopathology 90:354-361.

31. Van der Zaag, D. E. 1956. Overwintering en epidemiologie van Phytophthora infestans, tevens enige nieuwe bestrijdingsmogelijkheden. Tijdschr. Planteziekten. 62:69-156.

32. Zentmyer, G. A. 1981. The effect of temperature on growth and pathogenesis of Phytophthora cinnamomi and on growth of its avocado host. Phytopathology 71:925-928.

33. Zwankhuizen, M. J., Govers, F., and Zadoks, J. C. 1998. Development of potato late blight epidemics: Disease foci, disease gradients, and infection sources. Phytopathology 88:754-763. 